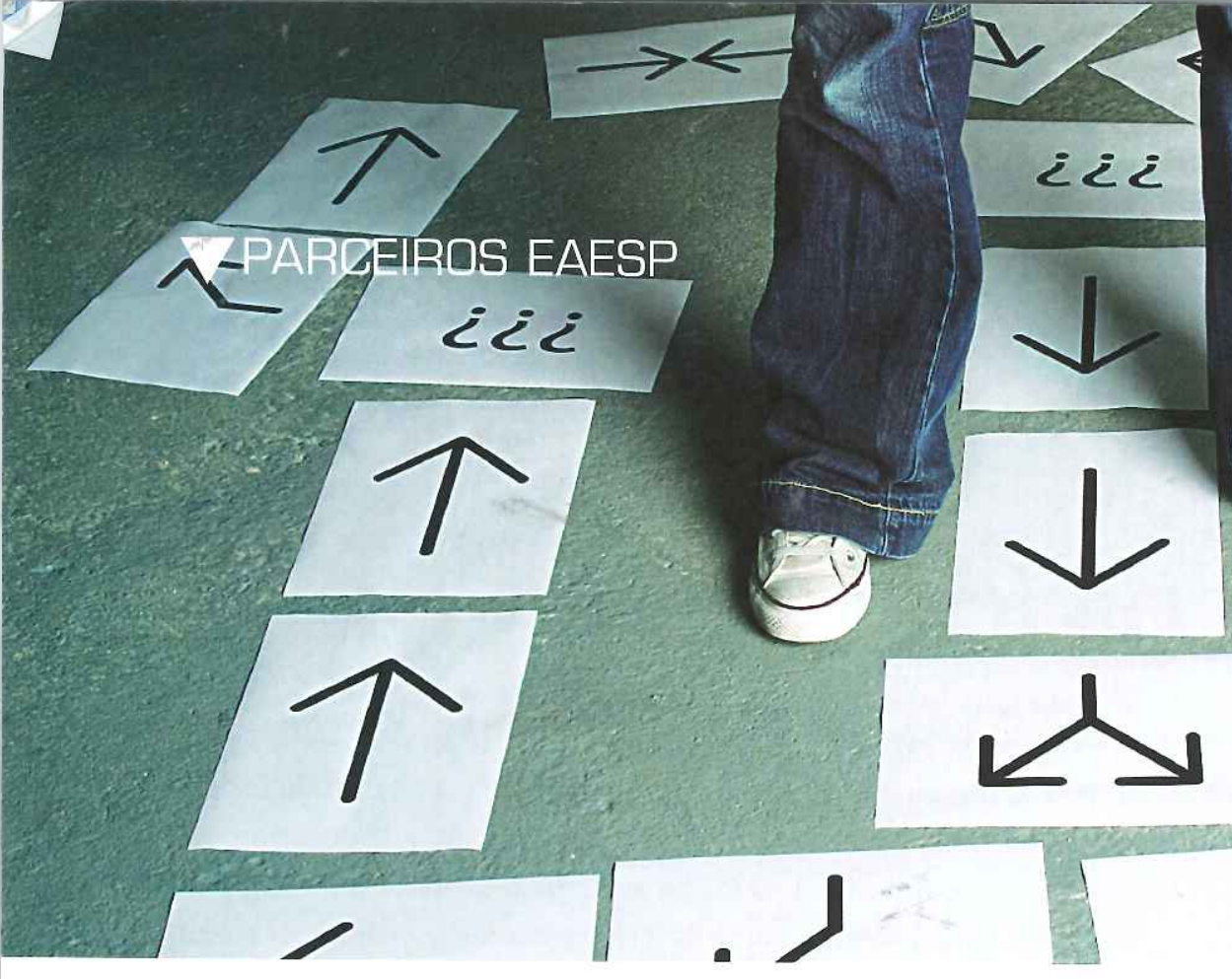

\title{
Um espaço de interlocução com as empresas
}

À medida que o estudante de Administração se aproxima do final do curso, começa também a enfrentar um desafio: é preciso encontrar um bom estágio, a fim de completar os conhecimentos adquiridos nos bancos escolares, e ao mesmo tempo iniciar a travessia rumo à vida profissional. Essa tarefa, que costuma ocupar os últimos semestres do curso, em geral não é simples, podendo até mesmo se tornar um quebracabeça difícil de resolver. Sobrecarga de trabalho, ansiedade, comprometimento das horas de estudo, entre outros problemas, são bastante comuns nessa fase da vida.

Pensando nisso, já há muito tempo a FGV-EAESP mantém um importante espaço em que seus alunos podem interagir com empresas interessadas em recrutar. Inicialmente chamada de Setor de Estágios, a iniciativa surgiu na década de 1970 com a finalidade de manter um banco atualizado de vagas para consulta dos alunos. Com o tempo, sua atuação no setor foi se ampliando, até que em 1996, com base em experiências trazidas das principais escolas de Administração norte-americanas, esse setor se transformou na Coordenadoria de Estágios e Colocação Profissional (Cecop).

Desde então, a Cecop vem auxiliando alunos e ex-alunos da EAESP não só da graduação como também dos diferentes cursos de pós - que estejam interessados em estágios, programas de trainee ou empregos efetivos.

PARA CONHECER OUTRAS ATIVIDADES DA CECOP E SABER COMO ELA PODE PARTICIPAR DA SUA INSERÇÃO NO MERCADO, CONSULTE A INTRANET ACADÊMICA OU ENTRE EM CONTATO: CECOP@FGV.BR

MISSÃO DA CECOP

Atender os alunos e ex-alunos da EAESP, tanto no nível de graduação como no de pós-graduação, tendo em vista os seus objetivos de desenvolvimento profissional.

\section{ATIVIDADES}

Para tanto, ela mantém uma forte atuação fora dos muros da escola, relacionando-se com mais de 3 mil empresas interessadas em recrutar estagiários, trainees e funcionários.

Divulgação de vagas por meio de murais localizados em pontos estratégicos da escola, e também pela intranet acadêmica (wuw.gv.br). Atualmente são divulgadas 4 mil vagas por ano, $40 \%$ delas de estágio.

Aconselhamento a alunos e ex-alunos sobre temas relacionados à colocação profissional: processos seletivos, elaboração de currículo, preparação para entrevistas etc.

\section{Assessoria a empresas que} desejem recrutar alunos da EAESP, inclusive com a utilização de salas de entrevista da escola em seus processos seletivos.

Career Meeting: Encontro anual de recrutamento em que os alunos têm a oportunidade de interagir com representantes de empresas que oferecem vagas de estágio, trainee ou emprego, e conhecer as oportunidades e os benefícios oferecidos. Este ano, será realizado no dia 31 de agosto, das 10:30 às 14:30 horas, na quadra de esportes da EAESP.

Workshops de carreira voltados a alunos da graduação, em parceria com a Companhia de Talentos, consultoria com mais de duas décadas de experiência na condução de programas de estágio e trainee. 